\title{
PENGARUH MODEL PEMBELAJARAN BERBASIS PROYEK \\ TERHADAP KEMAMPUAN MENULIS KARYA ILMIAH \\ GEOGRAFI SISWA SMA
}

\author{
Arif Baidowi $^{1}$, Sumarmi ${ }^{2}$, dan Achmad Amirudin ${ }^{3}$ \\ SMAN 1 Campurdarat Tulungagung ${ }^{1}$, Universitas Negeri Malang ${ }^{2,3}$ \\ Email: anginsamudera@gmail.com, sumarmi.fis@um.ac.id, \\ ach.amirudin.fis@um.ac.id
}

\begin{abstract}
The aim of this researchis to examine the effect of project-based learning model toward the writing ability of geography scientific papers on senior high school students. The subjects of the research are students of class XI IPS SMAN 1 Campurdaratconsists of two classes. The both class are class XI IPS 1 as the control class and XI IPS 2 as experimentclass. The instrument is used to measure the ability to write scientific papers geography using the rubric of scientific papersassessment. Results were analyzed using independent samples t test with SPSS 20.0 for Windows. The results showed an average gain score of writing ability of geography scientific papers for experiment class is higher than the control class. The results of independent samples t test analysis showed that the project-based learning model significantly affect toward the writing ability of geography scientific papers on senior high school students.
\end{abstract}

Keywords: Project-Based Learning, Writing Ability of Geography Scientific Papers

\section{PENDAHULUAN}

Model pembelajaran berbasis proyek merupakan bentuk pembelajaran yang berpusat pada siswa, bertujuan untuk mengembangkan kemandirian lebih pada diri siswa (Sumarmi, 2012: 172). Model pembelajaran ini memberikan kesempatan kepada siswa untuk merencanakan aktivitas belajar secara mandiri dalam kegiatan kerja proyek. Nurohman (2007) menjelaskan bahwa pembelajaran berbasis proyek memberikan kebebasan kepada siswa untuk merencanakan aktivitas belajar, melaksanakan proyek secara kolaboratif, dan menghasilkan produk kerja.

Model pembelajaran berbasis proyekmemiliki kelebihan dalam meningkatkan hasil belajar dan motivasi siswa. Thomas (2000) mengemukakan bahwa pembelajaran berbasis proyek dapat meningkatkan pencapaian prestasi akademik, pemahaman yang mendalam terhadapbahan ajar, dan meningkatkan motivasibelajar. Departemen Pendidikan Amerika Serikat (dalam SSME, 2006) menjelaskan bahwa tugas-tugas pembelajaran berbasis proyek 
berpengaruh positif terhadap motivasi, pemahaman, dan unjuk kerja siswa.

Pembelajaran berbasis proyek mendorong siswa untuk kreatif dan mandiri menghasilkan produk sebagai hasil pembelajaran. PGHP (2008) menyatakan bahwa implementasi model pembelajaran berbasis proyekmendorong pengembanganproduk pembelajaran secara nyatasesuai dengan kegiatan sebenarnya,yang secara alami membuat siswamengalami pembelajaran yang bermakna. Pengembangan produk inimenumbuhkan sikap positif siswa terhadap lingkungan sekitarnya.

Pembelajaran berbasis proyek memberikan pengalaman siswa untuk mem-bangun pengetahuannya sendiri. CORD (2007) mengemukakan bahwa model pembelajaran berbasis proyek bermaksud mendorong siswa belajar lebih dalam dengan menggunakan inkuiri. Sedangkan guru berperan sebagai fasilitator yang membimbing siswa untuk memperoleh pengalaman yang memungkinkan siswa dapat mengkonstruksi pemahaman secara mandiri Krajcik dkk., (dalam SSME, 2006).

Penggunaan model pembelajaran berbasis proyek juga memiliki kelebihan dalam meningkatkan kemampuan siswa menulis karya ilmiah. Turyantana (2013) menyimpulkan bahwa penerapan model pembelajaran berbasis proyek dapat meningkatkan hasilbelajar siswa hingga tercapainya tingkat ketuntasan hasil belajar siswa pada kegiatan menulis karya ilmiah siswa kelas XI IPS 1 SMA Saraswati Seririt. Marlinda (2012) menyimpulkan bahwa terdapat pengaruh yang signifikan penggunaan model pembelajaran berbasis proyek terhadap kemampuan berpikir kreatif dan kinerja ilmiah siswa.

Pada kompetensi dasar mata pelajaran geografi SMA menyebutkan kompetensi siswa yaitu dapat mengomunikasikan contoh tindakan dalam bentuk karya ilmiah. Hal ini dapat dilihat pada kompetensi dasar kelas XI IPS, yaitu: (1) mengomunikasikan sebaran flora dan fauna di Indonesia dan dunia berdasarkan karakteristik ekosistem dan region iklim dalam bentuk artikel ilmiah, makalah, atau bahan publikasi lainnya; dan (2) mengomunikasikan contoh tindakan yang tepat dalam pelestarian lingkungan hidup kaitannya dengan pembangunan berkelanjutan dalam bentuk makalah atau bentuk publikasi lainnya (Kemendikbud, 2013).

Rendahnya kemampuan siswa dalam menyusun karya ilmiah menyebabkan 
Arif Baidowi, Sumarmi, Ach. Amirudin. Pengaruh Model Pembelajaran Berbasis Proyek Terhadap Kemampuan Menulis Karya Ilmiah Geografi Siswa Sma

pencapaian kompetensi menjadi tidak maksimal. Wardarita(2012) menyebutkan rendahnya kemampuan siswa dalam menulis karya ilmiah dipengaruhi oleh beberapa sebab, yaitu: (1) siswa tidak memiliki kemampuan menulis, (2) guru jarang memberikan tugas latihan menulis karya ilmiah secara individu karena kurang waktu dan takut tidak tercapainya target pembelajaran, dan (3) metode pembelajaran yang dilakukan guru adalah ceramah, latihan, dan penugasan yang dilakukan secara klasikal. Oleh karena itu,diperlukan upaya agar siswa mampu mencapai kompetensisecara maksimal. Upaya yang dilakukan yaitu menggunakan model pembelajaran yang tepat. Artinya, modelpembelajaran yang dapat membawa siswa dalam kegiatan ilmiah sebagai upayapeningkatan kemampuan menulis karya ilmiah ilmiah. Adanya kelebihan model pembelajaran berbasis proyek menjadi pilihan sebagai model pembelajaran yang diharapkan dapat meningkatkan kemampuan siswa dalam menulis karya ilmiah. Melalui pembelajaran berbasis proyek, siswa dilatih untuk terampil dalam kegiatan ilmiah, seperti: keterampilan observasi lapangan, kemampuan analisis, mengorganisasi data, membuat laporan, dan presentasi. Di samping itu, pembelajaran tidak hanya terjadi di ruang kelas melainkan juga di lingkungan sekitar. Guru bukan satusatunya sumber belajar bagi siswa, tetapi siswa dapat menggali sumber belajar lain baik dari lingkungan sekolah maupun dari lingkungan masyarakat. Berdasarkan alasan tersebut, maka dilakukan penelitian tentang pengaruh model pembelajaran berbasis proyekterhadap kemampuan menulis karya ilmiah geografi siswa SMA.

\section{METODE}

Penelitian ini menggunakan rancangan penelitian eksperimen semu(quasi experimental design). Bentuk desain eksperimen semu dalam penelitian ini menggunakan non-equivalent control group design. Kemampuan menulis karya ilmiah siswa ditentukan dari nilai produk awaldan produk akhir. Nilai produk awal diperoleh dari penilaian produk karya ilmiah geografi siswa sebelum pembelajaran. Nilai produk akhir diperoleh dari penilaian produk karya ilmiah geografi siswa sesudah pembelajaran. Alokasi penulisan karya ilmiah saat sebelum dan sesudah 
pembelajarandibuat sama, yaitu selama tiga minggu.

Penelitian ini dilaksanakan di SMA Negeri 1 Campurdarat. Subjek penelitian ini menggunakan dua kelas yang diambil dari kelas XI IPS tahun pelajaran 2014/2015 yaitu kelas XI IPS 1 dan kelas XI IPS 2. Penentuan subjek penelitian ini dilakukan dengan memilih dua kelas yang memiliki nilai tengah semester yang hampir sama pada mata pelajaran geografi. Hal ini untuk memenuhi syarat homogen. Selanjutnya dilakukan pengundian untuk menentukan kelas eksperimen dan kelas kontrol. Hasil pengundian diperoleh kelas XI IPS 2 sebagai kelompok eksperimen dan kelas XI IPS 1 sebagai kelas kontrol.

Variabel dalam penelitian ini terdiri dari: (1) model pembelajaran berbasis proyek (2) model pembelajaran biasa (ceramah, tanya jawab, dan penugasan), dan (3) kemampuan menulis karya ilmiah geografi. Berdasarkan variabel tersebut diuji ada tidaknya perbedaan antara penggunaan model pembelajaran berbasis proyek dan model pembelajaran biasa terhadap kemampuan menulis karya ilmiah geografi siswa.

Instrumen dalam penelitian ini menggunakan rubrik penilaian karya ilmiah. Rubrik tersebut berfungsi untuk mengukur kemampuan menulis karya ilmiah geografi siswa. Rubrik penilaian karya ilmiah yang digunakan dalam penelitian ini diadaptasi dari format penilaian karya ilmiah Lomba Penelitian Ilmiah Remaja (LPIR) SMA/MA Tingkat Nasional Tahun 2014 dalam rangka Lustrum XII Universitas Negeri Malang (UM).

Analisis data yang digunakan sebagai uji hipotesis dalam penelitian ini adalah analisis kemampuan menulis karya ilmiah geografi siswa. Teknik analisis yang digunakan adalah uji beda (independent sampel $t$ test) pada nilai/taraf signifikansi $\alpha=0,05$. Proses analisis data dilakukan melalui bantuan program SPSS 20.0 for Windows.

\section{HASIL}

Hasil rata-rata nilai produk awal pada kelas eksperimen yaitu 47,84 sedangkan pada kelas kontrol 48,18. Nilai rata-rata yang diperoleh kedua kelas yaitu kelas kontrol dan eksperimen terdapat perbedaan tetapi tidak terlalu besar. Dengan demikian, kelas kontrol dan eksperimen dianggap memiliki kemampuan awal setara. Pada kelas eksperimen diperoleh rata-rata nilai nilai produk akhir 75,04 sedangkan kelas 
Arif Baidowi, Sumarmi, Ach. Amirudin. Pengaruh Model Pembelajaran Berbasis Proyek Terhadap Kemampuan Menulis Karya Ilmiah Geografi Siswa Sma

kontrol diperoleh rata-rata nilai produk akhir 68,69 .

Kemampuan menulis karya ilmiah geografi dalam penelitian ini ditentukan berdasarkan selisih antara nilai produk awal dan nilai produk akhiryang disebut gain score. Nilai tersebut diperoleh dengan cara mengurangi nilai produk akhir dari masing-masing subjek dengan nilai produk awal. Nilai gain score ini menggambarkan kemampuan menulis karya ilmiah geografi dari keseluruhan subjek, baik kelas kontrol maupun eksperimen. Berdasarkan data nilai gain score diketahui bahwa nilai rata-rata kelas kontrol adalah 20,50 dan kelas eksperimen yaitu 27,19. Angka tersebut menunjukkan bahwa nilai rata-rata kelas eksperimen lebih tinggi daripada kelas kontrol.

Berdasarkan hasil analisis data melalui uji beda(independent sampel $t$ test) diketahui bahwa nilai signifikansi (sig)kurang dari 0,05 (sig < 0,05) yaitu sig 0,00 . Hal ini berarti $\mathrm{H}_{0}$ (pembelajaran berbasis proyek tidak berpengaruh signifikan terhadap kemampuan menulis karya ilmiah geografi siswa SMA) ditolak dan $\mathrm{H}_{1}$ (pembelajaran berbasis proyek berpengaruh signifikan terhadap kemampuan menulis karya ilmiah geografi siswa SMA) diterima.

\section{PEMBAHASAN}

Berdasarkan hasil uji hipotesis menunjukkan bahwa model pembelajaran berbasis proyek berpengaruh signifikan terhadap kemampuan menulis karya ilmiah geografi siswa. Hasil penelitian ini menguatkan temuan dari beberapa hasil penelitian sebelumnya, yaitu: (1) hasil penelitian Turyantana menyimpulkan bahwa terdapat peningkatan hasil belajar siswa hingga tercapainya tingkat ketuntasan hasil belajar pada kegiatan menulis karya ilmiah siswa kelas XI IPS, dan (2) hasil penelitian Marlinda menyimpulkan bahwa terdapat pengaruh yang signifikan penggunaan model pembelajaran berbasis proyek terhadap kemampuan berpikir kreatif dan kinerja ilmiah siswa.

Pengaruh yang signifikan model pembelajaran berbasis proyek terhadap kemampuan menulis karya ilmiah geografi siswa diduga karena hal berikut. Pertama, siswa menjadi tertantang untuk menyelesaikan permasalahan nyata melalui kegiatan proyek menulis karya 
ilmiah geografi. Hal ini dibuktikan ketika guru memberikan pilihan antara menggunakan permasalahan real di sekitar lingkungan tempat tinggal atau menggunakan masalah yang dapat ditemukan pada buku ataupun internet. Sebanyak 95\% siswa memilih menggunakan permasalahan nyata. Siswa beralasan bahwa menggunakan permasalahan nyata di lapangan akan lebih menarik dan menantang karena langsung berhubungan dengan kehidupan sehari-hari. Siswa merasa tertantang untuk mencari jawaban dari permasalahan lingkungan yang ditemukan melalui proyek penulisan karya ilmiah geografi.

Temuan di atas didukung oleh Wena (2012) yang mengungkapkan bahwa kerja proyek memuat tugas-tugas yang kompleks berdasarkan kepada pertanyaan dan permasalahan yang menantang, menuntut siswa untuk merancang, memecahkan masalah, membuat keputusan, melakukan kegiatan investigasi, dan memberikan kesempatan untuk bekerja secara mandiri. John (dalam Moerdiyanto \&Sunarta, 2011) mengatakan bahwa pembelajaran berbasis proyek lebih menekankan pada pemecahan masalah autentik yang terjadi sehari-hari melaluipengalaman belajar praktik langsung di masyarakat.

Kedua, siswa menjadi lebih aktif dalam pembelajaran. Hal ini dibuktikan dari temuan selama pembelajaran, siswa aktif mengikuti kegiatan proyek dari awal sampai akhir pembelajaran. Di awal pembelajaran siswa telihat aktif mengidentifikasi masalah lingkungan dan menyusun rencana proyek penulisan karya ilmiah geografi. Pada pelaksanaan penelitian di lapangan, siswa terlihat aktif melakukan observasi lapangan dan wawancara di lokasi penelitian. Ketika penulisan hasil dan pembahasan setelah observasi lapangan, siswa aktif mencari sumber teori baik dari buku di perpustakaan maupun browsing internet di laboratorium komputer. Di samping itu, siswa juga aktif melakukan bimbingan langsung kepada guru dan melakukan revisi pada penulisan karya ilmiah geografi.

Ketiga, kinerja siswa dalam menyelesaikan proyek lebih tertata. Hal ini karena aktivitas siswa didasarkan pada perencanaan atau desain proyek dan jadwal pelaksanaan proyek yang telah dibuat di awal. Sebelum melaksanakan proyek, siswa melakukan perencanaan dengan membuat desain proyek dalam hal ini membuat proposal penelitian. 
Arif Baidowi, Sumarmi, Ach. Amirudin. Pengaruh Model Pembelajaran Berbasis Proyek Terhadap Kemampuan Menulis Karya Ilmiah Geografi Siswa Sma

Selanjutnya siswa menyusun jadwal pelaksanaan proyek mulai pengalokasian waktu untuk pembuatan proposal penelitian, pengumpulan data, sampai pada penulisan akhir laporan dengan batas waktu yang jelas. Hal tersebut mempengaruhi kinerja siswa dalam melaksanakan proyek menjadi tertata sampai proyek selesai.

Keempat, siswa lebih memiliki kebebasan dalam menyelesaikan proyek. Hal ini karena pembelajaran berbasis proyek memberikan kebebasan kepada siswauntuk membuat rencana dan menyusun jadwal penyelesaian proyek. Siswa diberikan kebebasan untuk melakukan bimbingan langsung kepada guru mengenai perkembangan proyek. Demikian pula kebebasan untuk mencari dan mendapatkan informasi melalui kajian literatur, observasi, dan browsing di internet untuk mendukung penelitiannya.

Hal ini sejalan dengan pendapat The George Lucas Educational Foundation (2005) menjelaskan bahwa pembelajaran berbasis proyek memberikan kesempatan kepada siswa untuk menggali konten (materi) dengan menggunakan berbagai cara yang bermakna bagi dirinya dan melakukan eksperimen secara kolaboratif.
Nurohman (2007) menyimpulkan bahwa model pembelajaran berbasis proyek memberikan kebebasan siswauntuk merencanakan aktivitas belajar, melaksanakan proyek secara kolaboratif, dan pada akhirnya menghasilkan produk kerja yang dapat dipresentasikan kepada orang lain.

Kelima, siswa termotivasi untuk bersaing menghasilkan produk yang terbaik. Ciri pembelajaran berbasis proyek yaitu menghasilkan produk pada akhir pembelajaran sebagai salah satu sumber penilaian guru terhadap hasil belajar siswa. Hal ini mendorong siswa untuk berlomba-lomba menghasilkan produk yaitu karya ilmiah geografi yang terbaik untuk memperoleh penilaian yang maksimal dari guru. Hal ini didukung oleh hasil kajian yang dilakukan Departemen Pendidikan Amerika Serikat(ED) dalam SSME (2006) menunjukkan adanya pengaruh positif tugas-tugas pembelajaran berbasis proyek terhadap motivasi, pemahaman, dan unjuk kerja siswa. Susanawati (2013) menyimpulkan bahwa model pembelajaran berbasis proyek dapat meningkatkan motivasi belajar, melatih kreativitas siswa dan meningkatkan 
kemampuan berpikir kritis dan kognitif siswa.

Keenam siswa menjadi lebih mandiri dan memiliki tanggung jawab terhadap proyek yang dikerjakan. Adanya batas waktu pengerjaan proyek dan produk yang harus dihasilkan mendorong siswa untuk bertanggung jawab terhadap proyek yang dikerjakan. Hal ini dibuktikan dengan banyaknya siswa secara mandiri melakukan bimbingan langsung kepada guru di luar jam pelajaran. Melalui kegiatan bimbingan tersebut, siswa memperoleh pengalaman melakukan revisi dan editing terhadap penulisan karya ilmiah. Hal ini mendorong siswa untuk bersikap mandiri dan tidak menunggu bantuan dari teman lain atau kelompok lain dalam menyelesaikan proyek.

Hal tersebut didukung oleh Krajcik dalam SSME (2006) bahwa pembelajaran berbasis proyek mendorong siswa untuk bertanggung jawab terhadap belajarnya sehingga menjadi siswa yang mandiri. Wena (2012) mengemukakan bahwa kerja proyek memuat tugas-tugas yang kompleks berdasarkan kepada pertanyaan dan permasalahan yang menantang, menuntut siswa untuk merancang, memecahkan masalah, membuat keputusan, melakukan kegiatan investigasi, dan memberikan kesempatan kepada siswa untuk bekerja secara mandiri.

Dibandingkan dengan penelitian sebelumnya yaitu penelitian Turyantana (2013) dan Marlinda (2012), penelitian ini lebih memfokuskan pada keterampilan siswa dalam menulis karya ilmiah yang diperoleh dari penilaian produk siswa. Sedangkan penelitian sebelumnya lebih berorientasi pada hasil belajar kognitif siswa yang diperoleh dari nilai tes. Persamaannya yaitu sama-sama menggunakan model pembelajaran berbasis proyek dan menggunakan siswa SMA kelas XI IPS sebagai subjek penelitian. Oleh karena itu, hasil penelitian ini dapat melengkapi penelitian sebelumnya dalam menguji model pembelajaran berbasis proyek dalam mempengaruhi variabel selain hasil belajar kognitif siswa, yaitu kemampuan menulis karya ilmiah siswa.

Dalam penelitian ini juga ditemukan beberapa kelemahan dalam pelaksanaannya. Kelemahan tersebut antara lain: pertama, membutuhkan waktu yang relatif lama dalam penyelesaian proyek. Untuk menghasilkan produk karya ilmiah geografi, siswa memerlukan waktu selama enam kali pertemuan (tiga 
Arif Baidowi, Sumarmi, Ach. Amirudin. Pengaruh Model Pembelajaran Berbasis Proyek Terhadap Kemampuan Menulis Karya Ilmiah Geografi Siswa Sma

minggu). Hal ini disebabkan pengerjaan proyek siswa (penyusunan karya ilmiah geografi) melibatkan kegiatan penulisan mulai penyusunan desain proyek, jadwal pelaksanaan proyek, sampai pada pelaksanaan proyek. Hal tersebut membutuhkan waktu yang relatif lama. Selain itu, penyelesaian proyek tidak cukup hanya di dalam kelas, tetapi juga di lapangan untuk pengumpulan data. Hal ini sebagaimana pendapat Susanti (2008) mengemukakan bahwa walaupun sudah mengatur alokasi waktu yang cukup, masih saja pembelajaran berbasis proyek memerlukan waktu yang lebih banyak untuk pencapaian hasil yang maksimal.

Kedua, menuntut kemandirian dan tanggung jawab siswa terhadap penyelesaian proyek. Dalam pembelajaran berbasis proyek membutuhkan keaktifan, kemandirian, dan tanggung jawab siswa terhadap proyek yang dikerjakan. Kurangnya faktor tersebut menyebabkan pelaksanaan pembelajaran proyek tidak maksimal. Kurang kemandirian dan tanggung jawab ini ditandai dengan adanya beberapa siswa yang terlalu bergantung dengan temannya sehingga lebih suka menunggu pekerjaan teman ataupun instruksi guru. Oleh karena itu, guru dituntut untuk bekerja lebih dalam menjaga motivasi siswa agar tetap bekerja dengan baik dan memfasilitasi siswa agar dapat menyelesaikan proyek secara maksimal.

\section{KESIMPULAN}

Bertolak dari temuan penelitian dan pembahasan, hasil penelitian dapat disimpulkan bahwa model pembelajaran berbasis proyek berpengaruh signifikan terhadap kemampuan menulis karya ilmiah geografi siswa SMA. Di samping itu, juga ditemukan beberapa kelebihan dari model pembelajaran berbasis proyek, antara lain: (1) mendorong siswa menjadi tertantang untuk menyelesaikan permasalahan nyata di lapangan melalui kegiatan proyek, (2) siswa menjadi aktif dalam pembelajaran, (3) kinerja siswa dalam menyelesaikan proyek lebih tertata, (4) siswa lebih memiliki kebebasan dalam menyelesaikan proyek, (5) siswa termotivasi untuk bersaing menghasilkan produk yang terbaik,dan (6) siswa menjadi lebih mandiri dan memiliki tanggung jawab terhadap proyek yang dikerjakan. 


\section{DAFTAR RUJUKAN}

CORD. 2007. Project-Based Learning, (Online), (http://www.cord.org/projectbased-learning), diakses 20 April 2014.

Kemendikbud. 2013. Kompetensi Dasar Geografi SMA/MA. Jakarta: Kemendik-bud.

Marlinda, P.M. 2012. Pengaruh Model Pembelajaran Berbasis Proyek terhadap Kemampuan Berpikir Kreatif dan Kinerja Ilmiah Siswa. Tesis tidak diterbitkan, (Online), (http://pasca.undiksha.ac.id/eournal/index.php/jurnal_ipa/article/ viewFile/483/275), diakses 23 Desember 2013.

Moerdiyanto \& Sunarta. 2011. Penguasaan Kepribadian dan Keterampilan Bisnis Melalui Model Project Based Learning bagi Remaja Putus Sekolah Korban Gempa Sebagi Usaha Pengentasan Kemiskinan Di Kabupaten Bantul. Artikel Jurnal RPS 2, (Online), (http://staff.uny.ac.id/sites /default/files/penelitian/Dr.\% 20Moerdiyanto,\%20M.Pd./ARTIK EL\%20JURNAL\%20RPS\%202\%2 OMURDI-SUNARTA\%2011.pdf), diakses 1 Maret 2014.

Nurohman, S. 2007. Pendekatan Project Based Learning sebagai Upaya Internalisasi Scientific Method Bagi Mahasiswa Calon Guru Fisika. Artikel Jurusan Pendidikan Fisisk FMIPA UNY, (Online), (http://staff. uny.ac.id/sites/default/files/132309 687/project-based-learning.pdf), diakses 26 Pebruari 2014.

PGHP. 2008. Inovasi Project Base Learning, (Online). (http://gatothp2000. word- press.com/2008/02/27/sionet), diaks es tgl 21 Oktober 2014.

SSME, 2006. Project-Based Learning, (Online).(http://ssme.fedu.metu.edu .tr/ssme/index 2.php?option=com_c ontrnt\&do_pdf=1\&id=94), diakses 22 Oktober 2014.

Sumarmi. 2012. Model-Model Pembelajaran Geografi. Malang: Aditya Media Publishing.

Susanawati, E. 2013. Pembelajaran Project-Based Learning untuk Pembelajaran Kimia Koloid Di SMA. Jurnal MIPA Universitas Negeri Medan. 3 (2): 106112.

Susanti, E. 2008. Pembelajaran ProjectBased Learning, (Online), http://www.bobpearlman.org/BestP ractise/PBL_Research.pdf), diakses 20 Oktober 2014.

The George Lucas Educational Foundation. 2005. Instructional Module ProjectBased Learning, (Online).

(http://www.edutopia.org/modules/ PBL/whatpbl. php), diakses tanggal 21 April 2014.

Thomas, J.W., 2000. A Review of Research On Project-Based Learning. Supported by The Autodesk Foundation 111 McInnis Parkway San Rafael, California, (Online), (http:/www.autodesk.com/foundati on), diakses 20 Nopember 2014.

Turyantana, IK. 2013. Penerapan Model Pembelajaran Berbasis Proyek untuk Meningkatkan Aktivitas dan Tercapainya Ketuntasan Hasil Belajar Menulis Karya Ilmiah Siswa Kelas XI IPS 1 SMA Saraswati Seririt. Artikel Jurusan Pendidikan Bahasa dan Sastra Indonesia Universitas Pendidikan Ganesha, (Online). (http://download. portalgaru- 
Arif Baidowi, Sumarmi, Ach. Amirudin. Pengaruh Model Pembelajaran Berbasis Proyek Terhadap Kemampuan Menulis Karya Ilmiah Geografi Siswa Sma

da.org/article.php?article $=22433 \& \mathrm{v}$ al=1349), diakses 26Nop 2014.

Wardarita, Ratu. 2014. Kemampuan Menulis Karya Ilmiah Pendekatan Pembelajaran Kontekstual dan Penalaran Verbal. Yogyakarta: Pararaton.
Wena, M. 2012. Strategi Pembelajaran Inovatif Kontemporer (Suatu Tinjauan Konseptual Operasional). Jakarta : Bumi Aksara. 